\title{
A New Box Framework for E-Campus Interview Training
}

\author{
Varun Shenoy, \& P. S. Aithal \\ Srinivas Institute of Management Studies, Srinivas University, Mangalore - 575 001, INDIA. \\ E-mail: varun_shenoy@rediffmail.com
}

Type of the Paper: Research Analysis Paper.

Type of Review: Peer Reviewed.

Indexed In: OpenAIRE.

DOI: http://dx.doi.org/10.5281/zenodo.887923.

Google Scholar Citation: IJAEML

\section{How to Cite this Paper:}

Shenoy, Varun., \& Aithal, P. S. (2017). A New Box Framework for E-Campus Interview Tranining. International Journal of Applied Engineering and Management Letters (IJAEML), 1(2), 17-26.

DOI: http://dx.doi.org/10.5281/zenodo.887923.

International Journal of Applied Engineering and Management Letters (IJAEML)

A Refereed International Journal of Srinivas University, India.

(C) With Authors.

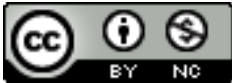

This work is licensed under a Creative Commons Attribution-Non Commercial 4.0 International License subject to proper citation to the publication source of the work.

Disclaimer: The scholarly papers as reviewed and published by the Srinivas Publications (S.P.), India are the views and opinions of their respective authors and are not the views or opinions of the S.P. The S.P. disclaims of any harm or loss caused due to the published content to any party. 


\title{
A New Box Framework for E-Campus Interview Training
}

\author{
Varun Shenoy, \& P. S. Aithal \\ Srinivas Institute of Management Studies, Srinivas University, Mangalore - 575 001, INDIA \\ E-mail: varun_shenoy@rediffmail.com
}

\begin{abstract}
Employers in the job market are constantly making paradigm change in their recruitment functions every moment involving various electronic mediums, social media, and ICT (Information \& Communication Technologies) in order to simplify the recruiting processes without compromising the objective of identifying suitable, best human resources for their vacancies. Present campus recruitment training methodologies employed for training students are yielding unproductive whilst tested with advanced interview methodologies of new age industry recruiters may adopt E-HRM practice to find the optimum solution to their challenges. Therefore, in this paper, a new e-campus interview training model known as "The Box Framework for E-Campus Interview Training” is proposed. Through conceptual study, by introducing various box contents of the framework, it is shown that a comprehensive online interview training plan can be designed by the trainer for a robust online e-interview preparation training program for the students. Evaluation of the training model option is also proposed under the new training framework. The four box model is expected to be most suitable and best method for E-campus interview training.
\end{abstract}

Keywords: Placement Training Models, E-Placement Training, Online Interview Training Frameworks, E-Training Model, E-Interview Training, Box Training Model.

\section{INTRODUCTION :}

Training young job seeking student for employment interview preparation has always been a challenging and continuous evolving process. Especially with rapid technological revolutions taking place in Human Resource management domain, training the fresh young students to rise up and match the industry requirements has become more intricate process. Georges (1996) in his work states that any soft-skill training must explain the measure of skilfulness required and also train until the defined measurable performance level and desired result are consistently achieved [1]. Now, achievement of above intention highly depends on the trainer and his/her trainees, the chalked-out training plan or program and as well the implementation method of the designed training program. However, Kirkpatrick (2006) introduced methodologies to evaluate his own highly applied and used "Four Level" model for training course evaluation which he invented during late sixties [2-3]. The present day and age involves e-recruitment through intense application of technologies and social media in entire recruitment process plus HR back end or operations which also otherwise known as e-HRM. Therefore, as of today, there is no known established structured e-interview facing training program for training the job seeking students at campus. This could be for attributed reasons like the interview rounds during the interview is oscillative in nature structured by the recruiter as per varied requirements of job role, its nature, client requirements, customer needs and employment markets rendering the education institution delivered training ineffective. In short, oneself is unable to determine exact quantity of match between the training component with actual interview component or industry requirement due to lack of time in exchanging requirement information between academia and industry at regular intervals. Normally, there will be a time volatility when academic board of studies amends syllabus to match industry or placement cell implements the skills training ; where given in fact the variables change in market every moment affecting corporate thereby causing students deprive of changed requirements and need to adjust to corporate environment. This is the 
reason why corporates or industry again invest resources in training new employees for taking up the job roles. However, with a view to contribute to the society and humanity, a research need was felt to develop a healthy growth oriented interview training model from educational institution, faculty or academics side for training job seeking students at campus for successfully facing E-HRM driven campus interview processes at job placement level. Therefore, this paper proposes a new Box Framework for E-Campus Interview Training to cater for the requirements of e-HRM and automated e-recruitment process in college or institutional campuses.

BOX Framework is training methodology that utilizes the deployment modules focused on specific training, critical growth requirements and development areas of employment seeking students; where job seeking students at campus are to be trained for becoming ready to face the challenge of e-hiring process at campus. The BOX Framework or 4 Box Model uses the training contents designed to train the students for catering the e-HRM requirements of the industry in a systematic matrix which is the quadratic box. The training focus areas under each deployment modules further include critical effective training elements, contents or constituents under the framework to be covered during training of focus for job seeking students/graduates. This training technique being simple and hybrid gives guidelines to identify and analyse the preparedness of any interview process training and new concepts or training programs be developed further there on if any.

\section{STUDY OBJECTIVES :}

The ideal objective of designing this study is to train the job seeking students/graduate community to improve their readiness or preparedness in facing modern advanced online e-campus interview processes. Primarily, the study seeks to fill the gap for a lack of a robust online e-recruitment training standard plan or program to prepare the job seeking graduate to face e-campus recruitment process. The model is also formulated with an objective of meeting the E-HRM standards and practices for benefit of the recruiter. Lastly, the research aims to be a simple accepted guiding framework or model for universal trainers in designing or formulating their own online e-interview preparation training program for campus placement seeking students.

\section{LITERATURE REVIEW :}

Various types of analysis, models, and frameworks are available in this new age for understanding the dimensions, workings and operational plans of institutions, companies, organizations, and firms. A satisfactory framework should facilitate towards a solution methodology distinctly suitable to the particular situation in question, which in this case is a need for an ideal online job interview preparation training framework for ensuring the success of students in advanced online campus interviews. Bartram (2000) research made a vision of human resource recruiting in future through technology with widening popularity of the internet or the world wide web[4]. Anderson (2003) presented a narrative review of research into applicant and recruiter reactions to new technology in employee selection during the internet time. Different aspects of the use of new technology were envisioned including computer-based testing, Internet-based recruitment and candidate assessment, telephone-based and video-based interviews, video-based situational judgment tests, and virtual reality scenarios making an agenda for future research in this direction [5]. Girard and Fallery (2009) presented about the continuous evolving electronic recruitment processes which have become the integral functions of HR today [6]. Career websites, Job Boards, Recruitment Systems is the major sourcing avenues and interviewing platforms for the majority of the company in the industry. The paper also argues that E-Recruitment saves a massive amount of precious resources like time, travel, cost and efforts. Sylva and Mol (2009) made a finding about the positive inclination of job seeking candidates about the online application procedure and its features [7]. Moreover, Furtmueller et al. (2011) put forward how industry Human Resource Department has embraced technology in the recruitment process and are managing the selection process along with recruitment events [8]. Holm (2012) propounded that industrial e-recruitment should become a universally accepted process and lead to a better candidate relationship management in portals and platforms. The findings indicate that e-recruitment transforms the traditional recruitment process into a time- and space-independent, collaborative hiring process [9]. Therefore, to match the rapid electronic HR recruitment function 
requirements of the industry in modern age, Shenoy and Aithal (2016 “a”) proposed a dynamic innovative online oriented industry placement model to make even the millions of job seeking students across the world as an integral part of e-recruitment process known as e-campus recruitment [10]. The Model spoke about effective application of online web platforms, social medias, audiovisual mediums, electronic communication mediums like e-mail and ICT (Information and Communication Technologies) to ensure the new automated campus recruitment function is carried out in an easy and smooth manner ensuring a win-win proposition for both industry and academia. Shenoy and Aithal (2016 "b”) also made a structured systematic analysis of "online oriented industry placement model" with a recent ABCD technique of model analysis Aithal et al. (2015) to test the rationality of the model [11-12].

\begin{tabular}{|c|c|c|}
\hline DEPLOYMENT MODULE 1 (DM1): & $1<$ BOX $>2$ & DEPLOYMENT MODULE 2 (DM2): \\
\hline TRAINING FOCUS AREAS I & & TRAINING FOCUS AREAS II \\
\hline $\begin{array}{l}\text { (1) Soft Skills Training for virtual electronic } \\
\text { processes } \\
\text { (2) Career Planning for trainees } \\
\text { (3) Goal Setting for trainees } \\
\text { (4) Introduction to ICT, Audio-Visual and } \\
\text { Electronic Communication } \\
\text { (5) Cover Letter \& Resume Building } \\
\text { (6) Online Profiling } \\
\text { (7) E-HRM }\end{array}$ & & $\begin{array}{l}\text { Practice online employment application } \\
\text { test involving: } \\
\text { (1) General Online Quantitative } \\
\text { Aptitude, } \\
\text { Reasoning, English and Current } \\
\text { Affairs, Data Sufficiency } \\
\text { (2) Functional Domain or Subject area } \\
\text { tests for which the job role or function } \\
\text { is offered or preferred }\end{array}$ \\
\hline DEPLOYMENT MODULE 4 (DM4): & $4<\mathrm{BOX}>3$ & DEPLOYMENT MODULE 3 (DM3): \\
\hline TRAINING FOCUS AREAS IV & & TRAINING FOCUS AREAS III \\
\hline $\begin{array}{l}\text { (1) Determination of Placement Quotient (PQ) } \\
\text { using IEDRA Model of Job Placement } \\
\text { Realization } \\
\text { (2) Test the trainees under conducting Full } \\
\text { Scale Online Mock and also under Live Online } \\
\text { Interviews with any recruiting company or } \\
\text { companies } \\
\text { (3) Evaluate the Learning outcome from } \\
\text { training \& Training effectiveness assessment } \\
\text { post Mock or Real E-Interviews through } \\
\text { IEDRA Rating Scoring Card for determining } \\
\text { the training impact } \\
\text { (4) Counselling }\end{array}$ & & $\begin{array}{c}\text { (1) Impart Online Group Discussion } \\
\text { and Practical Video-Conference facing } \\
\text { Training } \\
\text { (2) Impart Online Webinars and } \\
\text { Workshops } \\
\text { (3) Impart Telephonic Interview } \\
\text { Training } \\
\text { (4) Execute Online Panel and Face } 2 \\
\text { Face Direct Interview Training }\end{array}$ \\
\hline
\end{tabular}

Figure 1: Block diagram representation of Box Framework for E-Campus Interview Training with Deployment Modules and Training Focus Areas to be considered by the Campus Trainers.

The analysis identified the affecting factors for various determinant issues under four constructs advantages, benefits, constraints, and disadvantages. The analysis brought key critical constituent elements which satisfied the success for its existence. Later in the same year, Shenoy and Aithal (2016 "c") also proposed an innovative eco-friendly green campus placement process which spoke about application of online and digital interviews and e-student recruitment process to eliminate resource 
wastages and interview processes that caused hazard to the environment [13]. In 2017, Shenoy and Aithal (2017 "d") also discovered that there existed a stigma for a student in present competitive job market influenced by technology and e-HR practices to determine whether oneself is ready for job placement interview or not. A new IEDRA Model of employment placement readiness determination was proposed to cater the job seeking student a ready-made blueprint on which a decision on their placement readiness could be determined [14]. Any framework needs to always specify outcomes precisely, account for the effects of underlying and intervening variables that affect outcomes, and indicate inter- relationships. A confidence to sit in an interview will arise only when trainee undergoes all phases of training and practice the same. Holton (1996) exposed the flaws of four level evaluation model and proposed a new Conceptual Evaluation Model [15]. It described a sequence of influence on outcomes occurring on a single learning experience. A variety of training evaluation and its effectiveness research was carried across the professional space to construct an integrated model of training evaluation and effectiveness by various researchers. Alvarez et al. (2004) constructed a set of strict factors and investigated the evaluation and effectiveness of relationships with an evaluation measure proposed, post training attitudes [16]. Evaluation measures found to be related to post training attitudes were on to cognitive learning, training performance, and transfer performances.

\section{PROPOSITION OF THE FOUR BOX MODEL OR BOX FRAMEWORK FOR E-CAMPUS INTERVIEW TRAINING :}

The block diagram of 4 deployment modules of our proposed new model along with various training needs focusing areas are now shown in above figure. As Internet of Things (IOT), automation, digitization and artificial intelligence is emerging, the new dimension of business, industry, trade, commerce, and overall market has become more complex. According to this swing, many enterprises have focused establishing personnel training and selection models for creating a new value chain for their targeted stakeholders. Technology and Automation is also poised to play a major role in this area. Therefore, to match the manpower requirements of industry governed by e-HRM, the importance of developing a suitable student e-interview training model for educational institutions has been increasing more and more. This study is meaningful in suggesting integrated perspectives for analyzing and evaluating placement probability in the frame of reference towards students seriously looking for campus interviews and selections in an automated environment.

Table 1 : Training Focus Areas under Deployment Module 1 with Detailed Critical Effective Training Constituents under the framework to be covered during training under the 4 BOX Framework :

\begin{tabular}{|c|c|c|}
\hline \multirow[t]{2}{*}{$\begin{array}{l}\text { S.I. } \\
\text { No. }\end{array}$} & $\begin{array}{l}\text { DEPLOYMENT MODULE } 1 \\
\text { (DM1) }\end{array}$ & \multirow{2}{*}{$\begin{array}{l}\text { Detailed Critical Effective Training Constituents } \\
\text { under the framework to be covered during training } \\
\text { I }\end{array}$} \\
\hline & TRAINING FOCUS AREAS 1 & \\
\hline 1. & $\begin{array}{l}\text { Soft Skills Training for virtual } \\
\text { electronic processes }\end{array}$ & $\begin{array}{l}\text { (1) Professional behaviour \& courtesy in automated } \\
\text { and virtual environments } \\
\text { (2) Posture display while communicating via ICT, } \\
\text { Social Media rules and Audio-Visual Mediums, } \\
\text { Automation, Artificial Intelligence, Robotics and } \\
\text { Digital Literacy. }\end{array}$ \\
\hline 2. & Career Planning for trainees & $\begin{array}{l}\text { (1) Preparing MS-Word Documents with detailed } \\
\text { target deliverables during semesters at campus. } \\
\text { (2) Career and beyond the course completion planning } \\
\text { towards stepping stone directed at industry career. } \\
\text { (3) Identify Sectors in Economy and Industry, Job } \\
\text { Roles, Salary Packages, Work Ranks and Designations }\end{array}$ \\
\hline & & (1) Drafting realistic goals every semester to motivate \\
\hline
\end{tabular}




\begin{tabular}{|c|c|c|}
\hline 3. & Goal Setting for trainees & $\begin{array}{l}\text { \& achieve the professional drive of students } \\
\text { (2) Advising for any deviations thereon }\end{array}$ \\
\hline 4. & $\begin{array}{l}\text { Introduction to ICT, AV and } \\
\text { Electronic Communication }\end{array}$ & $\begin{array}{l}\text { ICT Handling exposure and simulation practice } \\
\text { training using Interactive Voice Response (IVR) } \\
\text { for trainees at electronic device laboratories }\end{array}$ \\
\hline 5. & Cover Letter \& Resume Building & $\begin{array}{l}\text { Conducting CV and Cover letter drafting workshops } \\
\text { or seminar }\end{array}$ \\
\hline 6. & Online Profiling & $\begin{array}{l}\text { Building profile presence in Facebook, twitter profiles } \\
\text { and LinkedIn for HR Visibility online for ensure short- } \\
\text { listing. }\end{array}$ \\
\hline 7. & E-HRM & $\begin{array}{l}\text { Apprise job seeking trainees about the below current } \\
\text { E-HRM concept in the Industry for their confidence } \\
\text { building boost } \\
\text { (1) Operational : } \\
\text { Concerned with Administrative Functions like Payroll } \\
\text { and Personnel Data Management using technology } \\
\text { (2) Relational : } \\
\text { Concerned with Supporting Business Processes like } \\
\text { Training, Recruitment, Hiring and Selection, } \\
\text { Performance Management using technology } \\
\text { (3) Transformational : } \\
\text { Concerned with Strategic HR Activities like } \\
\text { knowledge management and strategic orientation. }\end{array}$ \\
\hline
\end{tabular}

Table 2: Training Focus Areas under Deployment Module 2 with Detailed Critical Effective Training Constituents under the framework to be covered during training under the 4 BOX Framework :

\begin{tabular}{|c|c|c|}
\hline \multirow[t]{2}{*}{$\begin{array}{l}\text { S.I. } \\
\text { No. }\end{array}$} & $\begin{array}{l}\text { DEPLOYMENT MODULE } 2 \\
\text { (DM2): }\end{array}$ & \multirow{2}{*}{$\begin{array}{c}\text { Detailed Critical Effective Training Constituents } \\
\text { under the framework to be covered during } \\
\text { training II }\end{array}$} \\
\hline & TRAINING FOCUS AREAS II & \\
\hline 1. & General Online Quantitative Aptitude & $\begin{array}{l}\text { Analytical Reasoning, English Language, Numerical } \\
\text { Quantitative Abilities, Data Sufficiency, General } \\
\text { Awareness and Current Affairs. }\end{array}$ \\
\hline 2. & $\begin{array}{l}\text { Functional Domain or Subject Area } \\
\text { Training }\end{array}$ & $\begin{array}{l}\text { Technologies, Software, Programming, E-Marketing, } \\
\text { E-Human Resources, E-Accounting and Finance as } \\
\text { per the role requirements etc. }\end{array}$ \\
\hline
\end{tabular}

Table 3: Training Focus Areas under Deployment Module 3 with Detailed Critical Effective Training Constituents under the framework to be covered during training under the 4 BOX Framework :

\begin{tabular}{|c|c|c|}
\hline \multirow[t]{2}{*}{ S.I. No. } & $\begin{array}{c}\text { DEPLOYMENT MODULE } 3 \\
\text { (DM3) }\end{array}$ & \multirow{2}{*}{$\begin{array}{c}\text { Detailed Critical Effective Training Constituents } \\
\text { under the framework to be covered during } \\
\text { training III }\end{array}$} \\
\hline & TRAINING FOCUS AREAS III & \\
\hline 1. & $\begin{array}{l}\text { Online Group Discussion facing } \\
\text { training }\end{array}$ & $\begin{array}{l}\text { Introducing communication techniques via video- } \\
\text { conferencing software and platforms. Training on e- } \\
\text { soft skills like sitting postures, using computers, AV } \\
\text { devices, eye focusing on camera, voice modulation, } \\
\text { exercising patience during technical issues, technical } \\
\text { problem solving, social media handling skills. }\end{array}$ \\
\hline
\end{tabular}




\begin{tabular}{|l|l|l|} 
2. & Online Conference and Webinars & $\begin{array}{l}\text { Participating in workshops involving usage of Social } \\
\text { Media, Internet, ICT and Audio-Visual Mediums }\end{array}$ \\
\hline 3. & Telephonic Interview training & $\begin{array}{l}\text { Conducting Mock Conference Calls, Telephonic trial } \\
\text { interview rounds }\end{array}$ \\
\hline 4. & $\begin{array}{l}\text { Online Panel and } \\
\text { Face 2 Face Training }\end{array}$ & $\begin{array}{l}\text { Requisition training for online personal interviews } \\
\text { such as involving video chats or } \\
\text { conferencing, webinars, interview reporting time, } \\
\text { carrying laptops, professional behaviour. }\end{array}$ \\
\hline
\end{tabular}

Table 4: Training Focus Areas under Deployment Module 4 with Detailed Critical Effective Training Constituents under the framework to be covered during training under the 4 BOX Framework :

\begin{tabular}{|c|c|c|}
\hline \multicolumn{3}{|c|}{ DEPLOYMENT MODULE 4 (DM4): } \\
\hline \multicolumn{3}{|c|}{ TRAINING FOCUS AREAS IV } \\
\hline \multicolumn{3}{|c|}{$\begin{array}{l}\text { Detailed Critical Effective Training Constituents under the framework to be covered during } \\
\text { training IV }\end{array}$} \\
\hline \multicolumn{3}{|c|}{ 1. Determination of Placement Quotient (PQ) using IEDRA Model of Job Placement Realization } \\
\hline \multirow[t]{2}{*}{ S.I. No. } & \multirow[t]{2}{*}{ IEDRA Model Constructs } & Student Placement Determination \\
\hline & & $\begin{array}{l}\text { Performance Focus Areas and Deployment } \\
\text { Factors to be considered under constructs by the } \\
\text { student/graduate }\end{array}$ \\
\hline I & (I) Interested & $\begin{array}{l}\text { (1) Interest to attend job interviews both in } \\
\text { campus as well as direct with companies post } \\
\text { graduation. (2) Inherent interest by } \\
\text { student/graduate for need of a job or employment, } \\
\text { (3) interest to work and secure the job }\end{array}$ \\
\hline II & (E) Eligibility & $\begin{array}{l}\text { (1) Possess necessary marks criteria stipulated in } \\
\text { the job description/specification specified by } \\
\text { Employer, (2) Required Language requisites for } \\
\text { the job, (3) Necessary Functional \& Technical } \\
\text { Skillsets (4) Necessary domain/skill certifications } \\
\text { from professional agencies/institutions (5) } \\
\text { Required Work Experience }\end{array}$ \\
\hline III & (D) Desiring / Deserving & $\begin{array}{l}\text { (1) Honest Students/Graduate who carry, portray } \\
\text { and practice problem solving, right attitude, } \\
\text { aptitude and various soft/life skills. }\end{array}$ \\
\hline IV & (R) Registered & $\begin{array}{l}\text { (1) Registered with college placement cell, (2) } \\
\text { Registered for each specific recruitment drives }\end{array}$ \\
\hline \multirow[t]{2}{*}{$\mathrm{V}$} & (A) Acceptability & $\begin{array}{l}\text { (1) Honestly appears for the interviews (2) } \\
\text { Perform at the interviews (3) Success/Failure } \\
\text { probabilities at Job Interviews for review (4) } \\
\text { Interview Performance Evaluation }\end{array}$ \\
\hline & $\begin{array}{l}\text { Test the trainees under conducting } \\
\text { Full Scale Online Mock and also } \\
\text { under Live Online Interviews with any } \\
\text { recruiting company or companies }\end{array}$ & $\begin{array}{l}\text { (1) Arrange an Online Mock E-Interview at } \\
\text { campus involving rounds like: I. Interact \& Apply } \\
\text { to mock companies through Social Media or } \\
\text { uploading candidate profiles in mock websites or }\end{array}$ \\
\hline
\end{tabular}




\begin{tabular}{|c|c|c|}
\hline 2. & & $\begin{array}{l}\text { e-mail a write-up about your model analysis } \\
\text { about the recruiting companies II. Conduct an } \\
\text { online aptitude test or domain aptitude tests to } \\
\text { check the scores for shortlisting III. Call for an } \\
\text { Video-Conferencing Group Discussion and } \\
\text { shortlist IV. Conduct a face } 2 \text { face direct video } \\
\text { interview round towards Selection } \\
\text { OR } \\
\text { (2) Partner with real corporates who have adopted } \\
\text { E-HRM and monitor initial BOX deployment } \\
\text { module trained trainees as they progress towards } \\
\text { each stage in the online e-campus recruitment } \\
\text { process of the recruiting company. The interview } \\
\text { rounds of market recruiter may vary when } \\
\text { compared to mock or practice interviews. }\end{array}$ \\
\hline 3. & $\begin{array}{l}\text { Evaluate Learning outcome \& } \\
\text { Training effectiveness assessment post } \\
\text { Mock or Real E-Interviews through } \\
\text { IEDRA Rating Scoring Card }\end{array}$ & Refer Sample Annexure Table 5 \\
\hline 4. & Counselling & $\begin{array}{l}\text { For deserving and professional support seeking } \\
\text { candidates: } \\
\text { (1) Impart Career Therapy, } \\
\text { (2) Provide Career Motivation, } \\
\text { (3) Facilitate Career Support and Guidance }\end{array}$ \\
\hline
\end{tabular}

Table 5 : Sample IEDRA Interview Assessment Matrix

\begin{tabular}{|c|c|c|c|c|c|c|c|}
\hline $\begin{array}{c}\text { Serial } \\
\text { No. }\end{array}$ & $\begin{array}{c}\text { Student } \\
\text { Name }\end{array}$ & $\begin{array}{c}\text { Interviewer } \\
\text { Comments }\end{array}$ & $\begin{array}{c}\text { 1 Strong } \\
\text { (Totally } \\
\text { Ready) }\end{array}$ & $\begin{array}{c}\text { 2 Moderate } \\
\text { (Partially } \\
\text { Ready) }\end{array}$ & $\begin{array}{c}\text { 3 Weak (Needs } \\
\text { monitoring, } \\
\text { practice and } \\
\text { improvement) }\end{array}$ & $\begin{array}{c}\text { Trainer or } \\
\text { Self Remarks } \\
\text { (Optional) }\end{array}$ \\
\hline 1 & Arnold & & $\checkmark$ & & & \\
\hline 2 & Harish & & & & $\checkmark$ & \\
\hline 3 & Geetha & & & $\checkmark$ & & \\
\hline
\end{tabular}

\section{USES OF THE BOX FRAMEWORK :}

Box framework is instrumental in online student employment skills training model identification and selection. It is a strong tool, but it involves a great degree of subjective element in choosing the model towards implementation. It is best when used as a guide or base, and not as a prescription like contemporary business analysis tools used towards strategy formulation. Successful training models can depend on this framework to build on their advantages, identify the benefits and anticipate constraints and counter disadvantages to increase its impact among the trainees. The 4 boxes of the framework are also highly flexible and extended versions with added enhanced online job interview skills training focus area can also be bought out depending upon further research in the area. The Model can be implemented in stages depending upon academic program semesters determined by the trainer. 


\section{CONCLUSION :}

The proposed BOX framework or Four Box Model of e-campus interview training is a very simple and highly useful validated approach for designing online interview skills oriented e-training models. As shown in the constructs, almost all of the training constituents which have been suggested in the diagram can easily be classified within the framework under its primary focus areas consisting each deployment modules. This Model was mainly developed to meet the requirements of E-HRM functions of the present day technology driven employment market and recruiters. There, of course, remain a variety of non-classifiable compound factors in adopting this model, such as overall "calibre" and "usability", but precise and unanimous definitions of these tend to be reasonably indistinct anyways. Even these compound criteria can benefit from the framework since the constituent attributes implementable under the deployment modules focused on training areas in terms of trainees' critical success elements in the automated or electronic campus interviews can be evaluated or appraised as per the given framework.

\section{REFERENCES :}

[1] Georges, J. C. (1996). The Myth of Soft-Skills Training. Training, 33(1), 48-54.

[2] Kirkpatrick, D. L. (2006). Seven keys to unlock the four levels of evaluation. Performance Improvement, 45(7), 5-8.

[3] Kirkpatrick, D. L. (1967). Evaluation of training. Evaluation of Short-term Training in Rehabilitation Oregon Univ. ERIC, 3(1), 35-61.

[4] Bartram D. (2000). Internet recruitment and selection: Kissing frogs to find princes. International Journal of Selection and Assessment, 8(4), 261-274.

[5] Anderson N. (2003). Applicant and recruiter reactions to new technology in selection: A critical review and agenda for future research. International Journal of Selection and Assessment, 11(2/3), 121-136.

[6] Girard, Aurelie., Fallery, Bernard. (2009). E-recruitment: new practices, new issues, An exploratory study. Human Resource Information System, INSTICC Press, pp. 39-48.

[7] Sylva H., Mol S. T. (2009). E-recruitment: A study into applicant perceptions of an online application system. International Journal of Selection and Assessment, 17(1), 311-323.

[8] Furtmueller E., Wilderom C., Tate M. (2011). Managing recruitment and selection in the digital age: E-HRM and resumes. Human Systems Management, 30(1), 243-259.

[9] Holm., Anna B., (2012). E-recruitment: Towards an Ubiquitous Recruitment Process and Candidate Relationship Management, German Journal of Research in Human Resource Management, 26 (3), 241-259.

[10] Shenoy, Varun and Aithal, P. S. (2016 “a”). Changing Approaches in Campus Placements - A New Futuristic Model. International Journal of Scientific Research and Modern Education (IJSRME), 1(1), 766 - 776.

[11] Shenoy, Varun and Aithal, P. S. (2016 “b”). ABCD Analysis of On-Line Campus Placement Model. IRA-International Journal of Management \& Social Sciences, 5(2), 227-244.

[12] Aithal, P. S., and Shailashree, V. T., and Kumar, P. M. Suresh. (2015). A New ABCD Technique to Analyze Business Models \& Concepts. International Journal of Management, IT and Engineering, 5(4), 409-423.

[13] Shenoy, Varun and Aithal, P. S. (2016 “c”). Green Placement - An Innovative Concept \& Strategy in Campus Placement Model. IRA- International Journal of Technology \& Engineering, 4(3), 151-163.

[14] Shenoy, Varun and Aithal, P. S. (2017 “d”). A New IEDRA Model for Student Placement 
Realization. International Journal of Management, Technology, and Social Sciences (IJMTS), 2(2), 20-27.

[15] Holton, E. F. (1996). The flawed four-level evaluation model. Human resource development quarterly, 7(1), 5-21.

[16] Alvarez, K., Salas, E., \& Garofano, C. M. (2004). An integrated model of training evaluation and effectiveness. Human resource development Review, 3(4), 385-416. 